The Eastern Librarian, Volume 23(1), 2012, ISSN: 1021-3643 (Print). Pages: 37-50. Available Online: http://www.banglajol.info/index.php/EL

\title{
MEASURING THE JOB SATISFACTION OF FEMALE LIBRARY PROFESSIONALS WORKING IN THE HEALTH LIBRARIES IN DHAKA CITY
}

\author{
Farzana Sultana \\ Asst. Chief Librarian, Bangladesh College of Physicians \& Surgeons (BCPS) Mohakhali, \\ Dhaka, Email: fzana2001@yahoo.com \\ Bilkis Begum \\ Head and Associate Professor, Department of Library and Information Science Lalmatia \\ Mohila College Lalmatia Dhaka
}

\begin{abstract}
Job satisfaction is an important area to determine the view of the library professionals towards their job in the library. The study has been under taken to measure the level of job satisfaction of female health library professionals in Dhaka city and how do the job facets (MSQ, 1967) affect on job satisfaction of female health library professionals. There is a cross sectional observational study to see the level of job satisfaction among health library professionals. A standard questionnaire (MSQ, 1967) is used to measure the level of job satisfaction of the sample. The result shows that out of twenty job facets eleven facets are highly significant for the job satisfaction and nine facets quite insignificant for job satisfaction. The study shows independence, variety of work, social status of the job, supervision-human relation supervision-technical, moral values, authority, ability utilization, library policies and practices, scope of advancement, relation with co-workers, recognition of job done and achievement has significant effect on job satisfaction. Further more it noticed females are less satisfied at their job. Finally, the significant recommendations have been put forth to improve the level of job satisfaction of female health library professionals in Bangladesh.
\end{abstract}

DOI: http://dx.doi.org/10.3329/el.v23i1.12117

\section{KEYWORDS}

Job satisfaction, Library Professionals, Health Libraries, Bangladesh. 


\section{INTRODUCTION}

Digital devices are presently at the centre of development in all of fields. Libraries are currently undergoing profound changes due to digitization. The development of digital library has insightful effect not only on the client but also on professionals and also on the human resource management of the library. The digital library brings about changes in the activities of the library in terms of users, in job and in staffing as well. It is widely accepted that human factors is one of the key component of the digital libraries but relatively a little attention has been paid to the human and organizational factors in the library that directly contributed to the fruitfulness of the digital library. There are also many other issues, which effect its development of libraries globally.

Gender issue gains prominence after poverty and violence, particularly in developing countries. In the age of $21^{\text {st }}$ century males and females are equally contributing to the overall development. In the library field both of them are managing the information and resources of knowledge with the objector to some serve clients effectively. It is often found there is a big problem of variation in the percentages of existences of job in developing countries.

The ratio of females in the developing countries, particularly in Bangladesh is quite low in almost every profession. Lack of job opportunity for females is a big hindrance for the economical and social development of Bangladesh. In the digital era, the job satisfaction is one of the vital issues which are responsible for the poor employability of females. Statistically, discrimination within the job and different job related factors like; pay promotion, working condition, social status security, recognition etc are a major determinant, which decides satisfaction as a whole. In case of female job satisfaction, it is important because the result of the relationship between psychological factors and work outcome of individuals are the most significant aspects of the human life.

Job satisfaction is a complex phenomenon that can be variably interpreted. It is the absence of pain, oppressiveness and intolerance and also indeed enjoyment of work. Job satisfaction is one of the most enduring elusive constructs used in the study of industrial relations (Locke, 1976). Job satisfaction studies are based on emotional response of employees which is related with some socio-cultural, organizational and personal factors variables like pay, promotion, supervision, benefits, contingent rewards, operating procedures, co-workers, nature of work, working conditions, social status etc. 


\section{LITERATURE REVIEW}

Job satisfaction is an important area to determine the view of the employee towards their job. The term job satisfaction was first defined by Happock (1935) as a combination of psychological, physical and environmental circumstances that cause a person to say "I am satisfied with my job". One of the vital sign of deteriorating conditions in an organization is low job satisfaction. It is a cause of grievances, low productivity, disciplinary problems and other organizational conflicts.

An attempt has been taken to present review of literature pertaining to the job satisfaction of library professionals. There are so many researches have been conducted in the area of job satisfaction over the past few decades. The various authors described different background variables namely age, gender, level of education, marital status, institutions pay, promotion, working conditions, coworkers, job status, job security, recognition, supervision and social status as playing a significant role to determinate the degree of job satisfaction among different professionals.

As the libraries are roots and fruits of civilization, libraries cannot be accomplished without the human resources generally considered to be most important and particularly in the service oriented organization like the library. In the literature review, Khaleque \& Rahman (1987) and Alam et al. (2005) identified most of the job facets influenced the level of job satisfaction. On the other hand, Rahman, (1989) investigated that not only the job facets but also job stress influenced the job satisfaction of the employees. Therefore, Ashraf et al. (2009) highlighted some dependent variables like carrier growth, training and development, professionals appraisal, company loyalty, have relationship with job satisfaction. However, Rahman et al. (2009) studied the level of job satisfaction on the basis of some factors which are: self-actualization, inquisitiveness factors, aesthetic factors and comparison factors.

Therefore, different authors have measured the level of job satisfaction of the library professionals in the different country and most of the study (Parmeer \& East 1993, Ebru 1995, Leckie \& Brett 1997, Aspasia2004) revealed that various job related variables influenced the level of job satisfaction of the librarians. Therefore, Horenstein (1993) identified two prediction of job satisfaction perception and participation. However, Thornton (2000) and Karim (2008) identified some additional factors which were influenced on the level of job satisfaction of the library professionals - self-potentiality, communication, 
procedures, professional's assignment, isolation, physical condition of the library.

Consequently, study on job satisfaction of library professionals in Bangladesh is very less. From the literature review, it observed that salary, status and organizational climates greatly influenced the level of job satisfaction of the library professionals in the country. Research on job satisfaction among Bangladeshi library personnel particularly in professionals in health libraries is lacking. There is an opportunity to do research in this field which it will be immensely helpful to find out the actual scenario of the library personnel in Bangladesh. So, it is significant to identify the level of job satisfaction among library professionals in health libraries of Bangladesh which will be more effective for the health library professionals as well as health sector in the country.

\section{THE STATUS OF HEALTH LIBRARIES IN BANGLADESH}

Health library is one of the most effective ways of disseminating information to the people. It is acting as a vital role to improve living condition and quality of life. Like other basic need of the people, information is another basic requirement (Islam, 2006). To ensure the health care services, health libraries are playing a vital role by disseminating health related information to the health professionals in the country. However, in Bangladesh most of the health libraries are under the administrative authority of the ministry of health and family planning. At present, there are 73 medical colleges, 82 health related institutions in Bangladesh (MOHFW, 2009). The health science libraries in a developing country like Bangladesh are in the clutches of serious financial problems. There is the shortage of required fund, whatever fund is available cannot be utilized for non availability of necessary publications with the local books seller (Uddin, 1980). Moreover, the lack of trained staff has created cumulative deficiencies in organizing and managing the health libraries in Bangladesh. Absence of suitable positions with attractive status, salary and prospects discouraged the qualified and talented persons from making health librarianship a career in Bangladesh. Efficient professionals can best be utilized if they are satisfied with their job and high level of job satisfaction can ensure the productivity and the quality of services. In this context, job satisfaction is a major area to address in the library services urgently.

Health libraries in Bangladesh, as a whole, play an important role in the overall improvement in the country. Peoples are facing a perilous situation especially 
in health sector due to the lack of advanced knowledge and information. The needs of demonstrate the value and impact of library and information service continuous to be one of the major challenges for the library and information profession in the $21^{\text {st }}$ century (Marshall, 2007).

Health libraries and information centres will need to provide effective information services to its user. The quality and effectiveness of these services depend upon the library professionals. Job satisfaction is one of vital issue that can ensure the professionals to be sound at the job and also helps to accomplish their services effectively. Job satisfaction of health libraries in the country is an important issue for the improvement of this existing condition and to achieve the goals of this field.

Determining the level of job satisfaction point of view of female is a remarkable issue at present. In male dominated society, like Bangladesh, females get less priority due to unenthusiastic attitudes toward female and unfairness at job in the country. The greater effectiveness of any organization particularly service oriented organization like library greatly concern on its professionals and the quality of services also depends on them. In this respect, it is very important to give the priority on the issue that how the female library professionals are feeling to their job. Therefore, in order to determine the level of job satisfaction in female library professionals, working in the health libraries a study has to be taken into consideration.

\section{OBJECTIVES OF THE STUDY}

The objectives of this study are:

1. To measure the level of job satisfaction of female health library professionals in Dhaka city.

2. To know how the job facets affect the job satisfaction of female health library professionals.

3. To recommend a proper guideline to improve the level of job satisfaction of health library professionals in Bangladesh.

\section{HYPOTHESIS}

$\boldsymbol{H}_{1}:$ Job facets have significant influence on job satisfaction.

$\boldsymbol{H}_{2}$ : There is a gender gap in the level of job satisfaction among library professionals.

41 The Eastern Librarian-peer-reviewed journal in LIS since 1965 


\section{METHODOLOGY}

There are 73 medical colleges and 82 health related institutions in all over the country. Out of each 32 medical colleges and 50 health institutions are situated in Dhaka city (MOHFW, 2009). Since the majority of medical college, 32 out of 73 and health institutions, 50 out of 82 situated in Dhaka. Those health libraries having a collection range from 2,000 to 25,000 copies of books and at least two library professionals working in the library were considered for this study. Based on these criteria, the population of the study included the library professionals working in eight health libraries in Dhaka city. All library professionals of selected libraries were included in the study. The size of the population is 160 working health library professionals in Dhaka city. Among them 38 were asked to participate in the study.

\section{Data Collection Tools and Analysis}

Primary data was collected by using questionnaire to measure the level of job satisfaction of the health library professionals. A structured tool was divided by two sections: Section-I used to measure the level of job satisfaction of the health library professionals and it included the short form of Minnesota Satisfaction Questionnaire (MSQ 1967). Section II was designed to collect personal information from the respondents. In order to find out the relationship between job satisfaction and personal information of health library professionals, six total of nine items with varying scale ranging from one to six were prepared and administered .The Student's ' $t$ ' test, and ' $Z$ ' test statistical methods were used to test the hypothesis .

\section{RESULT}

A total of 38 health library professionals were invited to participate in the study, of them 31 participated. Their age ranged from 25 to 55 years. 16 of the participant were male. 28 of the participant were married. Their length of service ranged from 2.5 to 3.5 years. The questionnaire was based on Minnesota Satisfaction Questionnaire (MSQ) to measuring job satisfaction. For the purpose of the study, short-form of MSQ was used and tested in various organizations and on library personnel who are posted at different position. Each item of MSQ scale refers to reinforce to the work environment. Based on the twenty job facets like; activity, independence, variety, social status, supervision-human relation, supervision technical, moral values, security, social service, authority, ability utilization, library policies and practice, 
compensation, advancement, responsibility, creativity, working condition, coworker, recognition achievement. The short-form MSQ consists of three scales: Intrinsic Satisfaction, Extrinsic Satisfaction and General Satisfaction. Each answer was marked from 1 to 5 with the level of satisfaction on different aspects of their job. According to Manual for the Minnesota Satisfaction Questionnaire, 1967 a scoring system was followed to identify the response of the professionals. The respondent indicates how satisfied he/she is with the present job by providing his/her response among five alternative (extremely satisfied $=5$, very satisfied $=4$, satisfied $=3$, less satisfied $=2$, not satisfied $=1$ ).

Table 1: Job Facets and Job Satisfaction

\begin{tabular}{|l|l|l|}
\hline Job Facet & p value & Level of significant \\
\hline Activity & $>.05$ & Insignificant \\
\hline Independence & $<.05$ & Significant \\
\hline Variety & $<.01$ & Highly significant \\
\hline Social Status & $<.05$ & Significant \\
\hline Supervision-Human Relations & $<.01$ & Highly significant \\
\hline Supervision-Technical & $<.01$ & Highly significant \\
\hline Moral Values & $<.01$ & Highly significant \\
\hline Security & $>.05$ & Insignificant \\
\hline Social Services & $>.05$ & Insignificant \\
\hline Authority & $<.01$ & Highly significant \\
\hline Ability Utilization & $<.01$ & Highly significant \\
\hline Library policies and Practices & $<.01$ & Highly significant \\
\hline Compensation & $>.05$ & Insignificant \\
\hline Advancement & $<.01$ & Highly significant \\
\hline Responsibility & $>.05$ & Insignificant \\
\hline Creativity & $<.05$ & Significant \\
\hline Working Condition & $>.05$ & Insignificant \\
\hline Co-workers & $<.01$ & Highly significant \\
\hline Recognition & $<.01$ & Highly significant \\
\hline Achievement & $<.01$ & Highly significant \\
\hline
\end{tabular}

Note: value (<.05 significant), $\mathrm{p}$ value (<.01 highly significant) and $\mathrm{p}$ value ( $>.05$ insignificant).

There are twenty job facets and background variables have been considered in this study. In this study, the Student's ' $t$ ' test was considered to see if the score was significantly different job facets and job satisfaction. Most of the job facets i.e. independence ( $\mathrm{p}$ value <.05, significant), variety ( $\mathrm{p}$ value $<.01$, highly significant), social status ( $\mathrm{p}$ value $<.05$, significant), supervision-human relation ( $\mathrm{p}$ value $<.01$, highly significant), supervision- technical ( $\mathrm{p}$ value $<.01$, highly significant), moral value ( $\mathrm{p}$ value $<.01$, highly significant), authority ( $\mathrm{p}$ value,

43 The Eastern Librarian-peer-reviewed journal in LIS since 1965 
$<.01$, highly significant), ability utilization ( $\mathrm{p}$ value $<.01$, highly significant), library policies and practices ( $\mathrm{p}$ value $<.01$, highly significant), advancement ( $\mathrm{p}$ value, <.01, highly significant), creativity ( $\mathrm{p}$ value $<.05$ significant), coworkers ( $\mathrm{p}$ value $<.01$ highly significant), recognition ( $\mathrm{p}$ value $<.01$, highly significant), achievement ( $\mathrm{p}$ value <.01, highly significant) have significant relationship with job satisfaction of the professionals. Meanwhile other job facets i.e. activity ( $\mathrm{p}$ value $>.05$, insignificant), security ( $\mathrm{p}$ value $>.05$, insignificant), social services ( $\mathrm{p}$ value $>.05$, insignificant), compensation ( $\mathrm{p}$ value $>.05$, insignificant), responsibility ( $\mathrm{p}$ value $>.05$, insignificant), working condition ( $\mathrm{p}$ value $>.05$, insignificant) have not any significant relationship with job satisfaction of the professionals.

In this study, personal information like; sex is considered to identify whether background variable is influenced to the level of job satisfaction of the health library professionals.

Table 2: Sex of the respondents

\begin{tabular}{|l|l|l|}
\hline Sex & Frequency & Percent \\
\hline Male & 16 & 51.61 \\
\hline Female & 15 & 48.38 \\
\hline Total & 31 & 100 \\
\hline
\end{tabular}

The above table clearly indicates that male (51.61\%) and female (48.38\%) are almost equally employed in the selected health libraries. On the basis of above point of view, it is found that male $(\mathrm{N}=16,51.61 \%)$ and female $(\mathrm{N}=15$, $48.38 \%$ ) are almost equally employed in the health library where research was conducted. The equality of both may be due to the nature of the work or the favorable working condition.

Table: 3 Sex and Jobs

\begin{tabular}{|l|l|l|}
\hline Background Variable & p Value & Level of Significant \\
\hline Sex & $<.01$ & Highly significant \\
\hline
\end{tabular}

Note: $p$ value (<.05 significant), $p$ value (<.01 highly significant) and $p$ value (> 05 insignificant).

The Z-test was used to determinate the gender and job satisfaction of the respondents. The male, female ratio in the group A (highly satisfied group) was $4: 1\left(n_{1} 5\right)$ and the male, female ratio in the group B (moderately satisfied group)

44 The Eastern Librarian-peer-reviewed journal in LIS since 1965 
was $12: 14\left(\mathrm{n}_{2} 26\right)$. Z-test was used to see if the difference of the ratios were significant. The $\mathrm{z}$ score was $>3$ and the $\mathrm{p}$ value was <.01 (Highly significant). It seems that males are more satisfied with their jobs than their counterpart females.

In the view of the result hypothesis: Job facets have significant influence on job satisfaction is partially accepted and null hypothesis is that there is no significant influence between job facets and job satisfaction of the professionals is partially rejected. The second hypothesis: There is a gender gap in the level of job satisfaction among library professionals is accepted. The null hypothesis, that there is no gender gap in the level of job satisfaction among library professionals is rejected.

\section{DISCUSSION}

The library is a service-oriented organization. The main objective is to provide services to the concerned users. The quality of service mostly depends on the library personnel, who are involved in this service. Job satisfaction is an important factor, which influences the library personnel as well as the services, which they are rendering. In Bangladesh, there has been an overall lacking of library facilities in different institutions. But as more and more facilities are being established, the focus is now on getting maximum benefits from these institutions. There is more attention on getting better service from existing resources. To get better service from these individuals we have to look into their hope and inspirations. Proper motivation and job satisfaction are essential to bring out the most output from an individual in any situation. From 8 health libraries a total of 31 library professionals took part in the study. Male $(\mathrm{N}=16$, $51.61 \%)$ and female $(\mathrm{N}=15,48.38 \%)$ are almost equally employed in these libraries.

There are significant differences between job satisfactions based on gender. Results of this study indicate that female professionals are less satisfied than their male counterparts. There are several research has found the less satisfaction level of females. Oshagbemi (2000) also stated that female have less job satisfaction due to inequality in job related factors such as pay, promotion and job level. The researcher added to give equal opportunity to female. Hulin and Smith (1965) cited in Chui (1998) found that females carried lower satisfaction levels, which covered for example, rank and promotional opportunities. Contrary to the findings of this study, Clark (1997) cited in Donohue and Heywood (2004) found women to experience greater job

45 The Eastern Librarian-peer-reviewed journal in LIS since 1965 
satisfaction. Another study conducted by Tang and Talpade (1999) found significant differences between males and females in terms of job satisfaction. Their study found that males have higher satisfaction with remuneration in relation to females, whereas females have higher satisfaction with co-workers than their counterpart male.

In this study there is incoherent significant relationship found between job satisfaction and job facets of the health library professionals. It has been found that nearly all of job facets accept activity, job security, social status, salary, responsibility, working condition are significantly influenced the level of job satisfaction of the professionals. It is noticed to find that motivational factors are important to influence on the level of job satisfaction. Therefore, to determine satisfaction or dissatisfaction of employee, salary is an important variable than others. Lack of salary raises anxiety among employee and hindered hope of satisfying some desired wants, ambition or needs. It's a motivator as well as status symbol. But this study does not find any significant relationship between salary and job satisfaction. In the same way, working condition is also not found significantly influential to the job satisfaction though it is also important variable to determine the job satisfaction and it influences the employee both physical and psychologically. Similarly, Job security is more important for the employee's job satisfaction at their work place. It is more important to lower level than higher level. The findings of this study indicate that there was insignificant relationship between job security and job satisfaction. However, there are other imperative facets like activity, social services, responsibility found the relationship with job satisfaction.

Result of this study identified that the strongest relationship was obtained between job satisfaction and job related factors i.e. Variety, supervision-human relations, supervision-technical, moral values, authority, ability utilization, library policies and practice, promotion, co-workers, recognition, achievement have highly significant while independence, social status, creativity have weak significant influence on the level of job satisfaction of the professionals. The job facets like independence, variety, social status, supervision-human relations, supervision-technical, moral values, social status, authority, ability utilization, library policies and practices, promotion, creativity, co-workers, recognition and achievement are responsible for dissatisfaction of library professionals in health libraries in Bangladesh.

46 The Eastern Librarian-peer-reviewed journal in LIS since 1965 


\section{RECOMMENDATIONS}

To enhance the level of job satisfaction of the females, this study is recommended the following steps:

- The job status as social aspect of library professionals should be defined for the enhancement of job satisfaction. In our society the social status of library processionals and the influence they have in shaping the minds of people is yet to be acknowledged. The media can play a great role in educating the people. The role of libraries and library professionals may play in the thinking of a society, if given the opportunity. Only through building awareness, the people of the importance of the professionals, can the social status of the librarians be increased.

- The management of health libraries should be more flexible. They should carry the ability to develop the managerial structure, policies and practices in term of digital changes. They need to adapt a good entrepreneurial, innovative approach, elevating the motivation. They should also develop their managerial behaviour in terms of decision making process towards females.

- Supervisor should be trained on the technical aspect of their job. All the institutions should be equipped with modern up-to-date technologies for the developing of digital libraries. The supervisors need to be trained about the modern methods of human resource management. They should be provided with on the job training about these things from time to time. They should also be advised to give due praise where it is due.

- It should be given the same opportunity for promotion to females. The area of rewards most notable issues for the job satisfaction. Empowering, recognition and rewarding can increase the level of performance which repeatedly influences the level of job satisfaction

- Relation with co-workers seem to influence the level of job satisfaction in each individual particularly for females in male dominating environment, every institute should have a training program to train the staffs on how to get well along with each other.

- To provide training on digital libraries to the professionals. Continuous training is needed for female library professionals in health libraries in the country. The quality of training they received is moderate good to excellent. It can reduce the frustration to new changes at work. It is not only ensuring the professional development but also increase the level of their confidence. 
- Gender discrimination should be reduced in health libraries in the country. Gender inequality is an acute problem in all sectors in the country. It eliminates female from upper to lower position in job that badly impacts on female potentiality.

- Security at the work place should be ensured for the female library professionals. Perceived injustices, electronic surveillance, job insecurity, physical and psychological aggression create lack of selfesteem of females professionals at work.

- Social awareness should be created so that the male partner takes more responsibility for the families of working women

- Working environment should be a more woman friendly. Although females in developing countries like Bangladesh have had little contact with the new technologies but favourable working environment can make them interest to adjust with the new technological changes. Healthy working environment also helps to improve their lives and their family which directly influence their level of job satisfaction.

- Children day care centre should be establish in every institution. Females also have lots of responsibilities to their family. Keeping children in safe place make them sound in psychologically, it can stimulate to give their best effort at work.

- Why female are less satisfied with their job can be an issue for further study. This study also has recommended a bigger study to look into the cause.

\section{CONCLUSION}

Digital library needs digital professionals who are skilled, knowledgeable and experienced. Although the study identified that females are almost equally working at health libraries in the country. The role and function of female library professionals in library services is a subject that has been generally not received adequate attention in the country. Females are in naturally and traditionally treat as to be weak in the society because of lack of education and lack of opportunities in the job market. They become socially discriminated and they are deprived of employment in many of professions. As a result they lead an unsure life. This study has found that females are less satisfied with their job than their counterpart male. The research found the female professionals are statistically equal in the health related libraries in the country and surprising is that most of them are less satisfied with their job. So that care must be taken to develop of job satisfaction in aspect of job related factors like independence, 
variety, social status of the female professionals, good supervisory techniques, point of moral values, authority towards work, utilization of ability of female professionals, strong and favourable library policies and practices, balance in position, responsibility, promotion, recognition and achievement, maintain a good relationship with co-workers, encourage to using the creativity of the female professionals on their job and achieving the mental satisfaction towards job. These areas might be increased easily at the job satisfaction level of female health library professionals in Bangladesh. This measure will make them selfreliant and keep them on job for long-term employment. It is also notable that the previous way of running the libraries will have to entrance in digital agre in order to put on more responsibilities and more decision making power. So females in library profession should be more sound and satisfied at the job to achieve the goals of the digital libraries in health sector of Bangladesh.

\section{REFERENCES}

Alam, S. S., Tallha, M., Civanand, N. C. \& Ahsan, N. M., (2005). Job satisfaction of university women teachers in Bangladesh. Journal of Social Science, 1(2), 88-91.

Ashraf, M. A., Joarder, M. H. R. \& Al-Masum, R (2009). Job satisfaction of the employees in the mobile phone corporate in Bangladesh: a case study. AIUB Journal of Business and Economics, 8 (1), 1-16.

Aspasia, T. (2005). Measurement of burnout and the influence of background characteristics in Greek academic librarians. Library Management, 26(3), 130138.

Chiu, C. (1998). Do professional women have lower job satisfaction than professional men lawyers as a case study. Sex roles, 38(7/8), 521-537.

Clark, A. E. (1997). Job Satisfaction and Gender: Why women are so happy at work. Labour Economics, 4, 341-372.

Donohue, S. M. \& Heywood, J. S. (2004). Job satisfaction and gender: An expanded specification from the NLSY. International Journal of Manpower, 25( 2), 211-238.

Ebru, K. (1995). Job satisfaction of the librarian in the developing countries. $61^{\text {st }}$ IFLA General Conference Proceedings Aug 20-25.

Hoppock, R. (1935). Job satisfaction. New York: Harper and Row. 18-35.

Horenstein, B. (1993, May). Job satisfaction of academic libraries; an examination of the relationship between satisfaction, faculty status and participation. College \& Research Libraries, 54, 255-269.

Hulin, C. L. \&. Smith, P. C. (1995). A Linear Model of Job Satisfaction. Journal of Applied Psychology. 49, 209-216.

Islam , M. S. (2006). Status of rural library and information services in Bangladesh: direction for the development. The Social Science, 1(1), 15-21.

Karim, N. H. A. (2008). Investigating the correlates and predictors of job satisfaction 
among Malaysian academic librarians. Malaysian Journal of Library \& Information Science, 13(2), 69-88.

Khaleque, A \& Rahman, M. A. (1987). Perceived importance of job facets and overall job satisfaction in industrial workers. Human Relations, 40(7), 401-415.

Leckie, G. J. \& Brett. J. (1997). Job satisfaction of Canadian University Librarians: a national survey. College Research Libraries, January, 31-46.

Locke, E. A. (1976). The Nature and Causes of Job Satisfaction. In Marvin D Dunnette ed. Handbook of Industrial and Organizational Psychology. Skokie,III.: Rand McNally, 1297-1300.

Marshall, J. G. (2007). Measuring the value and impact of health library and Information Services: past reflection, future possibilities. Health Information and Libraries Journal, 24(suppl.1), 4-17.

MOHFW (Ministry of Health \& Family Welfare) (2009). Health Bulletin 2009. Dhaka:

Government of the People's Republic of Bangladesh, 1-181.

Oshagbemi, T. (2000). Gender differences in the job satisfaction of university students. Women in Management Review, 15(7), 331-343.

Parmer, C \& East, D. (1993, January). Job satisfaction among support staff in twelve Ohio academic libraries, College \& Research Libraries, 43-57..

Rahman, M. (1989). Job stress, satisfaction and mental health of factory workers in Bangladesh. Work Stress, 3(2), 155-162.

Rahman, M.I., Saha, S. \& Gurung, H. B. (2009). Where the job satisfaction of bank employees lies: an analysis of the satisfaction factors in Bangladesh. The Cost and Management, Journal of ICMAB, 34(3), 1-13.

Tang, T. L. \& Talpade, M. (1999). Sex differences in satisfaction with co-workers. Personnel Journal, 27(3), 5.

Thorton, J. K. (2000, May). Job satisfaction of librarian of African descent employed in ARL Academic Libraries. College Research Libraries, 217-232.

Uddin, M. J. (1980). Health science libraries in developing countries: two most important problems. Presented in Fourth International Conference on Medical Librarianship, (Health Information For a Developing World), YugoslaviaSeptember , 2-5. 1980, 35-48. 